\title{
HEMATO-BIOCHEMICAL AND MOLECULAR MARKERS (IS900) OF CATTLE INFECTED WITH JOHNE'S DISEASE IN EGYPT
}

\begin{abstract}
Ahmed M. Abdelaal ${ }^{1}$, Magdy M. Elgioushy ${ }^{2 *}$, Shaimaa M.Gouda ${ }^{1}$, Mohamed M. El-Adl ${ }^{3}$, Emad A. Hashish ${ }^{4}$, Shimaa A. Elgaml ${ }^{4}$, Mayar O. Ali ${ }^{5}$, Attia A El-Gedawy ${ }^{6}$

${ }^{1}$ Department of Animal Medicine, Faculty of Veterinary Medicine, Zagazig University, Zagazig 44511, Egypt, ${ }^{2}$ Department of Animal Medicine, Faculty of Veterinary Medicine, Aswan University, Aswan 37916, Egypt, ${ }^{3}$ Department of Biochemistry and Chemistry of Nutrition, Faculty of Veterinary Medicine, Mansoura University, Mansoura 35516, Egypt, ${ }^{4}$ Department of Clinical Pathology, Faculty of Veterinary Medicine, Zagazig University, Zagazig 44511, Egypt, ${ }^{5}$ Department of Animal welfare and Husbandry, Faculty of Veterinary Medicine, Mansoura University, Mansoura 35516, Egypt, ${ }^{6}$ Department of Bacteriology, Animal Research Institute, Egypt

${ }^{*}$ Corresponding author, E-mail: magdy.gioushy@aswu.edu.eg
\end{abstract}

\begin{abstract}
In Egypt, limited studies were performed to investigate Jhon's disease (JD) caused by Mycobacterium avium subspecies paratuberculosis (MAP). This study was concerned with diagnosis of MAP in cattle dairy farms using indirect-ELISA technique and amplification of IS900 using PCR technique for confirmation of infection and investigated adequate diagnostic markers for MAP through determining hemato-biochemical profile in cattle dairy farms. Screening of MAP was done by indirect ELISA between the periods from January 2017 to June 2018. A total of 200 cows suffered from persistent diarrhea $(n=17)$ and apparently healthy cows in contact with them $(n=183)$ were used in this study. Positive JD was reported in 62 cases (31\%) and negative JD was reported in 138 cases (69\%). Out of the positive JD, 17 cases were clinically affected by persistent diarrhea and weight loss (clinical JD), where 45 cases were apparently healthy (sub-clinical JD). Typical colonies of MAP were isolated from the fecal samples of clinically affected cows with positive staining of MAP bacilli. Amplification of IS900 using PCR technique confirmed the presence of MAP infection. Phylogenetic analysis revealed identical similarities with MAP strains in India and Egypt. Hemato-biochemical investigations revealed significant decrease in RBCs, PCV, total protein, globulin and glucose with non-significant change in oxidative stress markers in clinically affected cows. This study is considered one of the limited researches that highlight the role of MAP infection in dairy farms in Egypt.
\end{abstract}

Key words: dairy cattle; ELISA; IS900; Johne's disease; MAP

\section{Introduction}

Johne's disease is a chronic infectious enteric disease of ruminant where MAP is the causative agent of the disease. It is a slow growing, gram-positive and acid-fast bacterium that requires several months of incubation (1). Severe economic losses in the cattle industry were reported in farms infected with MAP (2). Ingestion of colostrum, water and feed contaminated with fecal matters via the fecal oral route can predispose to JD infection (3). 
The disease has a characteristic cross infection between species without restrictions, thus it is hard to be controlled (4). Vaccination may be effective in controlling infection and reduction shedding of MAP in the fecal matter with no complete elimination of infection (5). During the clinical stage of JD, the infection causes excessive diarrhea and wasting of the affected animal. Sub-clinically affected animals may, additionally, shed the bacterium with colostrum, milk and feces, particularly in the last stage of the disease (6). Furthermore, JD has zoonotic importance as MAP existed in the pathogenesis of Crohn's disease (CD) (7).

Several methods might be used for diagnosis of JD. Identification of MAP through fecal subculture consumes a long time and therefore it is not considered an appropriate method of diagnosis. Additionally, ELISA can be used for the detection of the immune reaction of the microorganism (8). Polymerase chain reaction (PCR) can be used in amplification of certain genes in MAP (9). Several specific genetic sequences for MAP have been identified, such as IS900, F57element, and hsp X gene. The IS900 is considered the target of choice and the most widely used for MAP detection (10).

The aim of the current study was to determine hemato-biochemical profile of cattle herds infected with MAP with the aid of indirect-ELISA technique and amplification of IS900 using PCR technique for confirmation of infection as well as to construct a phylogenetic analysis for determining the genetic difference between current infection and other infected strains in other localities.

\section{Materials and methods}

\section{Animals and clinical examination}

Two hundred dairy cows were selected from three dairy farms in Sharqia and Ismailia Governorates in Egypt during the period from January 2017 to June 2018. The selection of cows was based on the existence of persistent diarrhea in addition to all cows over 3 years of age in the same farms were also selected. Cows were classified into three categories based on the ELISA screening test. Clinically affected cows were classified based on positive ELISA results in association with persistent diarrhea $(n=17)$. The sub-clinically infected cows with Johne's disease was classified based on positive ELISA results without any clinical signs $(n=45)$. Out of the remaining negative cows $(\mathrm{n}=138), 15$ cows were randomly selected as negative control cows. All cows enrolled in this study received a thorough clinical examination via methods that have been previously described in cattle (11).

\section{Blood and fecal samples collection}

Blood samples were collected from the jugular vein of two hundred selected cows for the initial ELISA screening test. Seventy seven blood samples were collected from the clinically, sub-clinically and control cows for hemato-biochemical profile. Fecal samples were collected from clinically affected cows from the rectum for the bacteriological isolation, identification and amplification of IS900 using PCR technique.

\section{MAP antibodies titration}

Serum from all selected cows was examined for anti-MAP antibodies in ELISAs. To titrate anti-MAP antibodies, we used Mycobacterium paratuberculosis (MAP) test Kit for dairy cattle PARACHEK2 (Prionics, Switzerland) according to (12).

\section{Examination of fecal samples}

Fecal samples were collected from 17 clinically affected cows which were positive by ELISA and associated with persistent diarrhea. Two grams of fecal sample were collected from each animal and kept into a sterile mortar and decontamination of the fecal sample was done using $30 \mathrm{ml}$ of $0.9 \%$ Hexadecylpyridinium chloride solution (HPC), to $3 \mathrm{~g}$ of aliquot for 24 $\mathrm{h}$ through vortexing and shaking (13). After 30 min, at room temperature, $20 \mathrm{ml}$ of the supernatant was transferred into another sterile tube and placed for $24 \mathrm{~h}$ at room temperature in a dark place in a vertical position, and then the tubes were centrifuged for $10 \mathrm{~min}$ by $3000 \mathrm{rpm}$ (14). Three hundred $\mu$ l of the decontaminated pellet was used after discarding of the supernatant and inoculated with Herrold's egg yolk medium (HEYM) slants and supplementation with 
mycobactin J. One week incubation of slants was done in a horizontal position at $37^{\circ} \mathrm{C}$, and then the tubes were kept in a vertical position for 8-16 weeks incubation period. Later the tubes were being checked for the growth of typical MAP colonies. Then smears were taken, from the suspected samples for microscopic examination.

\section{Ziehl-Neelsen staining of fecal smears}

Prepared fecal smears were air dried for 10 minutes, followed by a heat fixation $\left(60-70^{\circ} \mathrm{C}\right)$, for $2 \mathrm{~h}$. The smears were dipped in carbol fuch$\sin 1 \%$, and then gently heated until a small portion of steam rises without reaching the boiling point. All slides were kept for 5-10 minutes, and then rinsed with tap water followed by addition of acid alcohol $(3 \% \mathrm{Hcl}$ in $70 \%$ methyl alcohol) for 1-2 minutes then thoroughly rinsed with tap water again. Slides were immersed in Methylene blue 5\%, and left for 1-2 minutes, then rinsed with tap water and dried in air. Finally, the slides were examined under oil immersion lens.

\section{Molecular detection of MAP using IS900}

Extraction of DNA from isolated MAP was carried out, using QIAamp DNA Mini kit (Qiagen, Germany), according to manufacturer's instruction. Amplification of IS900 MAP was performed on Bio-Rad T100 Thermal cycler (Hercules, CA, USA) with a 60 ng of DNA template, $12.5 \mu 1$ of Emerald master mix (Takara, Japan) and $2 \mu \mathrm{l}$ of forward and reverse primer for MAP IS900 marker (F: CCG CTA ATT GAG AGA TGC GAT TGG; R: AAT CAA CTC CAG CAG CGC GGC CTC G) (15). PCR was started with an initial denaturation step at $94^{\circ} \mathrm{c}$ for 10 minutes, then followed by 35 cycles of denaturation for 60 seconds at $94{ }^{\circ} \mathrm{c}$, annealing for 90 seconds at $61^{\circ} \mathrm{C}$ and extension for 60 seconds at $72{ }^{\circ} \mathrm{C}$ to amplify the fragment of DNA of $298 \mathrm{bp}$ for IS900. PCR products were then run on gel electrophoresis $(2 \%)$ for visualization of the amplified PCR product. The required product size was optimized using a 100bp DNA ladder (Jena bioscience, Germany) and was cut with a clean scalpel for purification of DNA fragment with Gene JET Gel extraction kit (Thermo Scientific, Lithuania). The purified DNA products were then sent for sequencing in 3130 X DNA Sequencer (Genetic Analyzer, Applied biosystem, Japan) with both forward and reverse primer used in PCR.

\section{Phylogenetic analysis}

The obtained nucleotide sequence was aligned, trimmed with the aid of ClustalW that was integrated with MEGA 6 software (16). The trimmed DNA samples were checked on Genbank for determining similarity index between other species of MAP on Genbank.

\section{Hematological analysis}

Two ml of blood samples were collected into EDTA tubes for the investigation of hematological parameters. Total RBCs count was manually done by using Neubauer-ruled hemocytometer. Hemoglobin $(\mathrm{Hb})$ concentration was determined using the method of cyanomethemoglobin (J.T. Baker, London, England). Packed cell volume (PCV) was determined by microhematocrit centrifugation. The value of PCV was determined by using a built-in reader. The erythrocytic indices, include mean corpuscular volume (MCV), mean corpuscular hemoglobin $(\mathrm{MCH})$ and mean corpuscular hemoglobin concentration (MCHC), were calculated from the value of total RBCs count, $\mathrm{Hb}$ concentration and PCV by using the standard formulas (17).

\section{Biochemical analysis}

Five $\mathrm{ml}$ of blood was collected into plain test tubes without anticoagulant. It was used for the separation of serum samples for the biochemical investigations. Blood left at room temperature for $2 \mathrm{~h}$ to be clotted, and then centrifuged at $3000 \mathrm{rpm}$ for $10 \mathrm{~min}$. All biochemical parameters were analyzed colorimetrically by commercial kits (BioMérieux, Marcy, L'Etoile, France). The serum glucose (18), serum cholesterol (19), triglycerides (20), serum total protein (21) and albumin (22) were measured. Globulin was calculated based on subtracting serum albumin from serum total protein. Liver transaminases (ALT \& AST) (23) and alkaline phosphatase (24) were determined. Creatinine (25) and urea (26) were also measured. 


\section{Antioxidant status and oxidative stress markers}

Several parameters were evaluated in the serum samples to measure the antioxidant status and stress markers. The total antioxidant capacity (TAC) was calculated (27), serum glutathione-S-transferase (GST) activity was estimated using Chloro dinitro benzene derivative (28). Reduced glutathione (GSH) concentration was colorimetrically determined using dithio dinitrobenzene derivatives (29). Hydrogen peroxide $\left(\mathrm{H}_{2} \mathrm{O}_{2}\right)$, malondialdehyde (MDA) and nitric oxide (NO) concentrations were determined colorimetrically according to (30-32), respectively.

\section{Statistical analysis}

Differences between subclinical, clinical JD and control cows were analyzed using the Kruskal-Wallis with post hoc Dunn's multiple comparison tests because of the non-normal distribution of markers. Results were presented as medians \pm standard errors (S.E.). The significance was determined at $P<0.05$. All statistical analysis was performed using the statistical software (SPSS Inc., Chicago, IL, USA).

\section{Results}

\section{Clinical signs}

Signs of clinically affected cows with JD were recorded, (Table 1). Clinically affected cows showed normal systemic reactions (body temperature, respiratory rate and heart rate). Persistent diarrhea, chronic loss of body weight, pronounced decrease in milk yield and dehydration (sunken eyes) were the most pronounced clinical signs observed in $100 \%$ of cases. Reduced ruminal sound, right ping sound and sub-mandibular edema were observed in $29.4 \%$ of clinically affected cows. Rectal palpation revealed corrugated rectal mucosa in $70.6 \%$ of cases. Diarrhea was watery, contains air bubbles. Marked reduction was observed in milk production in clinically affected cows when compared with sub-clinically infected cows and control (average milk production was $10 \pm 2.4 \mathrm{~kg} /$ day in clinically affected cows, $18 \pm 3.1 \mathrm{~kg} /$ day in sub-clinically infected cows and $21 \pm 5.3 \mathrm{~kg} /$ day in control cows).

\section{Detection of MAP antibodies}

The MAP antibodies were detected in the serum samples of clinically affected and sub-clinically infected dairy cows of two hundred investigated dairy cows for the presence of MAP IgG antibodies for in serum of cattle. Specific anti-MAP IgG antibodies were detected from the serum samples of the clinically infected cows $8.5 \%$ and sub-clinically affected cows $22.5 \%$, but no IgG antibodies were detected from the serum samples of the control cows.

\section{Isolation and microscopic examination of MAP}

MAP was usefully isolated from 4 out of 17 fecal samples of clinically affected cows which diagnosed by indirect ELISA. After 16 weeks of incubation on Herrold's media containing egg yolk slope, typical colonies of MAP were observed and appeared very small, convex (hemispherical), soft, non-mucoid and initially colorless and translucent. Staining of direct fecal smears revealed 3 of 17 fecal samples were positive. Microscopic appearance of MAP showed red acid alcohol-fast Ziehl-Neelsen staining bacilli.

The amplification of MAP DNA samples was sequenced, matched and deposited on Genbank with accession number of MH663496 and named as Mycobacterium avium subsp. paratuberculosis Egy1. The aligned MAP species are KY587112， KT075353， KT075351, KT075350, MH663496, KJ173784, JQ837281, EU130943, EF514831, EF536056, EF536046, S74401, AF416985, AF305073, AJ250018, AJ011838, AB052552, AJ250023, AJ251434, AJ250022, X16293, EF536047, AY974347, KT275243, EF536041, FJ775182, AY974346, JN983503, EU232747, EF514825, AF455252, EF536048, EU714039, EF514828, KJ173781, EU232756, EU714041, EU232748, HQ830160, EU057153, EU057170, EU714040, EU232755, KJ882903, HM172613, GQ144322. It showed a 100\% identity with MAP strain KVAFSU_S196. Phylogenetic tree (Fig. 1) was divided into two clades (clade A and B) where our isolated species of MAP was located in subclade B among other related species of M.avium (MAP strain 
KVAFSU_S196, MAP strain 25, MAP strain steroyl ACP desaturase, MAP strain B42, MAP strain 25C) that was isolated from India. Moreover, pairwise distance showed 0.0009 with our isolated strain. The Indian strain and our Egyptian strain were shown a close genetic distance with high node support. The highest pairwise difference was observed in JQ837281 (1.3 EU130943 (1.4), S74401 (1.3), AJ011838 (1.3) and KT275243 (1.4). Those species were located in different localities in Australia, India, and United Kingdom and in Egypt.

\section{Hematological analysis}

Clinically affected cows showed a significant $(P<0.05)$ decrease in the RBCs, PCV and the level of MCV with a significant $(P<0.05)$ increase in the level of MCHC, meanwhile the $\mathrm{Hb}$ concentration revealed a non-significant changes when compared with the control and sub-clinically infected group. The blood indices in this group reflect microcytic hyperchromic anemia. There was a non-significant change in the RBCs, Hb, PCV, MCV, and MCHC level in sub-clinically infected cows when compared with the control ones. The blood indices were close to the level of normal in this group, (Table 2).

\section{Biochemical parameters}

Table 1: Clinical picture of 17 cows affected by Johne's disease

Clinical signs

\section{Clinically affected cows by Johne's}

\begin{tabular}{lcc}
\cline { 2 - 3 } & Number of cows & \% \\
\hline Normal vital parameters* & 17 & 100 \\
Normal ruminal motility** & 12 & 70.6 \\
Hypomotile rumen & 5 & 29.4 \\
Right ping sound & 5 & 29.4 \\
Chronic weight loss & 17 & 100 \\
Persistent diarrhea & 17 & 100 \\
Dehydration (sunken eye) & 17 & 100 \\
Decrease in milk production & 17 & 100 \\
Submandibular edema & 5 & 29.4 \\
Corrugated rectal mucosa by rectal palpa- & 12 & 70.6 \\
tion & &
\end{tabular}

* Normal vital parameters mean normal reference range of temperature $\left(38.2-39.2^{\circ} \mathrm{C}\right)$, heart rate $(70-90 /$ minute $)$ and respiratory rate (20-30/minute) (11).

** Normal ruminal motility (3-5 ruminal contraction/2minute) (11). 
Table 2: Hematological picture in control, sub-clinically and clinically affected cows

\begin{tabular}{|c|c|c|c|}
\hline Parameter & $\begin{array}{c}\text { Control } \\
(n=15)\end{array}$ & $\begin{array}{l}\text { Sub-clinical Johne's } \\
\qquad(n=45)\end{array}$ & $\begin{array}{c}\text { Clinical Johne's } \\
(\mathrm{n}=17)\end{array}$ \\
\hline RBCs $10^{12} / \mathrm{L}$ & $5.8 \pm 0.19^{\mathrm{a}}$ & $5.85 \pm 0.16^{\mathrm{a}}$ & $3.97 \pm 0.18^{\mathrm{b}}$ \\
\hline $\mathrm{Hb} \mathrm{g} / \mathrm{dl}$ & $6.6 \pm 0.45^{\mathrm{a}}$ & $6.9 \pm 0.27^{\mathrm{a}}$ & $7 \pm 0.29^{\mathrm{a}}$ \\
\hline PCV \% & $38 \pm 1.17^{\mathrm{a}}$ & $35.1 \pm 0.85^{\mathrm{a}}$ & $21 \pm 1.5^{\mathrm{b}}$ \\
\hline $\mathrm{MCV} \mathrm{fl}$ & $65.32 \pm 0.9^{\mathrm{a}}$ & $60.4 \pm 0.32^{\mathrm{a}}$ & $53.03 \pm 0.8^{\mathrm{b}}$ \\
\hline MCH pg/ cell & $12.1 \pm 0.77^{\mathrm{b}}$ & $11.8 \pm 0.55^{\mathrm{b}}$ & $17.64 \pm 1^{\mathrm{a}}$ \\
\hline $\mathrm{MCHC} \%$ & $17.37 \pm .02^{\mathrm{b}}$ & $19.64 \pm 0.12^{\mathrm{b}}$ & $33.33 \pm .01^{\mathrm{a}}$ \\
\hline
\end{tabular}

Medians with different superscripts indicate significant difference at $P<0.05$

Table 3: Biochemical picture in control, sub-clinically and clinically affected cows

\begin{tabular}{llll}
\hline \multicolumn{1}{c}{ Parameter } & \multicolumn{1}{c}{$\begin{array}{c}\text { Control } \\
(\mathbf{n = 1 5})\end{array}$} & \multicolumn{1}{c}{$\begin{array}{c}\text { Sub-clinical Johne's } \\
(\mathbf{n = 4 5})\end{array}$} & \multicolumn{1}{c}{$\begin{array}{c}\text { Clinical Johne's } \\
(\mathbf{n = 1 7})\end{array}$} \\
\hline Glucose mg/dl & $48 \pm 4.5^{\mathrm{a}}$ & $45.45 \pm 1.9^{\mathrm{a}}$ & $38 \pm 4.1^{\mathrm{b}}$ \\
Cholesterol mg/dl & $157 \pm 11.2^{\mathrm{a}}$ & $165 \pm 10.6^{\mathrm{a}}$ & $169 \pm 21.2^{\mathrm{a}}$ \\
Triglycerides mg/dl & $49 \pm 3.17^{\mathrm{a}}$ & $55 \pm 2.55^{\mathrm{a}}$ & $58 \pm 4.7^{\mathrm{a}}$ \\
Total protein g/dl & $8 \pm 0.3^{\mathrm{a}}$ & $8.64 \pm 0.28^{\mathrm{a}}$ & $5.15 \pm 0.48^{\mathrm{b}}$ \\
Albumin g/dl & $3.52 \pm 0.28^{\mathrm{a}}$ & $3.8 \pm 0.15^{\mathrm{a}}$ & $3.15 \pm 0.31^{\mathrm{a}}$ \\
Globulin g/dl & $4.48 \pm 0.38^{\mathrm{a}}$ & $4.84 \pm 0.27^{\mathrm{a}}$ & $2 \pm 0.37^{\mathrm{b}}$ \\
ALT u/l & $10 \pm 0.4^{\mathrm{a}}$ & $13 \pm 0.66^{\mathrm{a}}$ & $11 \pm 0.62^{\mathrm{a}}$ \\
AST u/l & $19 \pm 0.81^{\mathrm{a}}$ & $16 \pm 0.85^{\mathrm{a}}$ & $18 \pm 0.77^{\mathrm{a}}$ \\
ALP u/l & $112 \pm 30.4^{\mathrm{a}}$ & $89 \pm 33.7^{\mathrm{a}}$ & $99 \pm 24.67^{\mathrm{a}}$ \\
Urea mg/dl & $25.06 \pm 2.83^{\mathrm{a}}$ & $20.14 \pm 2.97^{\mathrm{a}}$ & $17.17 \pm 2.76^{\mathrm{a}}$ \\
Creatinine mg/dl & $0.87 \pm 0.068^{\mathrm{a}}$ & $0.8 \pm 0.041^{\mathrm{a}}$ & $0.6 \pm 0.067^{\mathrm{a}}$ \\
\hline
\end{tabular}

Medians with different superscripts indicate significant difference at $P<0.05$

Table 4: Oxidative stress biomarkers in control, sub-clinically and clinically affected cows

\begin{tabular}{llll}
\hline \multicolumn{1}{c}{ Parameter } & \multicolumn{1}{c}{$\begin{array}{c}\text { Control } \\
(\mathbf{n = 1 5})\end{array}$} & $\begin{array}{c}\text { Sub-clinical Johne's } \\
(\mathbf{n = 4 5})\end{array}$ & $\begin{array}{c}\text { Clinical Johne's } \\
(\mathbf{n = 1 7})\end{array}$ \\
\hline GST u/L & $163.7 \pm 11.76^{\mathrm{a}}$ & $160.7 \pm 54.1^{\mathrm{a}}$ & $168.7 \pm 37.8^{\mathrm{a}}$ \\
GSH mg/d & $9.73 \pm 1.04^{\mathrm{a}}$ & $11.7 \pm 0.5^{\mathrm{a}}$ & $11 \pm 1.17^{\mathrm{a}}$ \\
TAC mM/L & $4.1 \pm 2.28^{\mathrm{a}}$ & $3.8 \pm 2.3^{\mathrm{a}}$ & $3.9 \pm 0.21^{\mathrm{a}}$ \\
$\mathrm{H} 2 \mathrm{O} 2 \mathrm{mM} / \mathrm{L}$ & $0.3 \pm 0.012^{\mathrm{a}}$ & $0.26 \pm 0.01^{\mathrm{b}}$ & $0.28 \pm .01^{\mathrm{ab}}$ \\
MDA nmol/ml & $6.6 \pm 1.3^{\mathrm{a}}$ & $6.2 \pm 1.2^{\mathrm{a}}$ & $5.6 \pm 0.9^{\mathrm{a}}$ \\
NO umol/L & $18 \pm 3.6^{\mathrm{a}}$ & $23 \pm 4.2^{\mathrm{a}}$ & $29 \pm 6.06^{\mathrm{a}}$ \\
\hline
\end{tabular}

Medians with different superscripts indicate significant difference at $P<0.05$ 


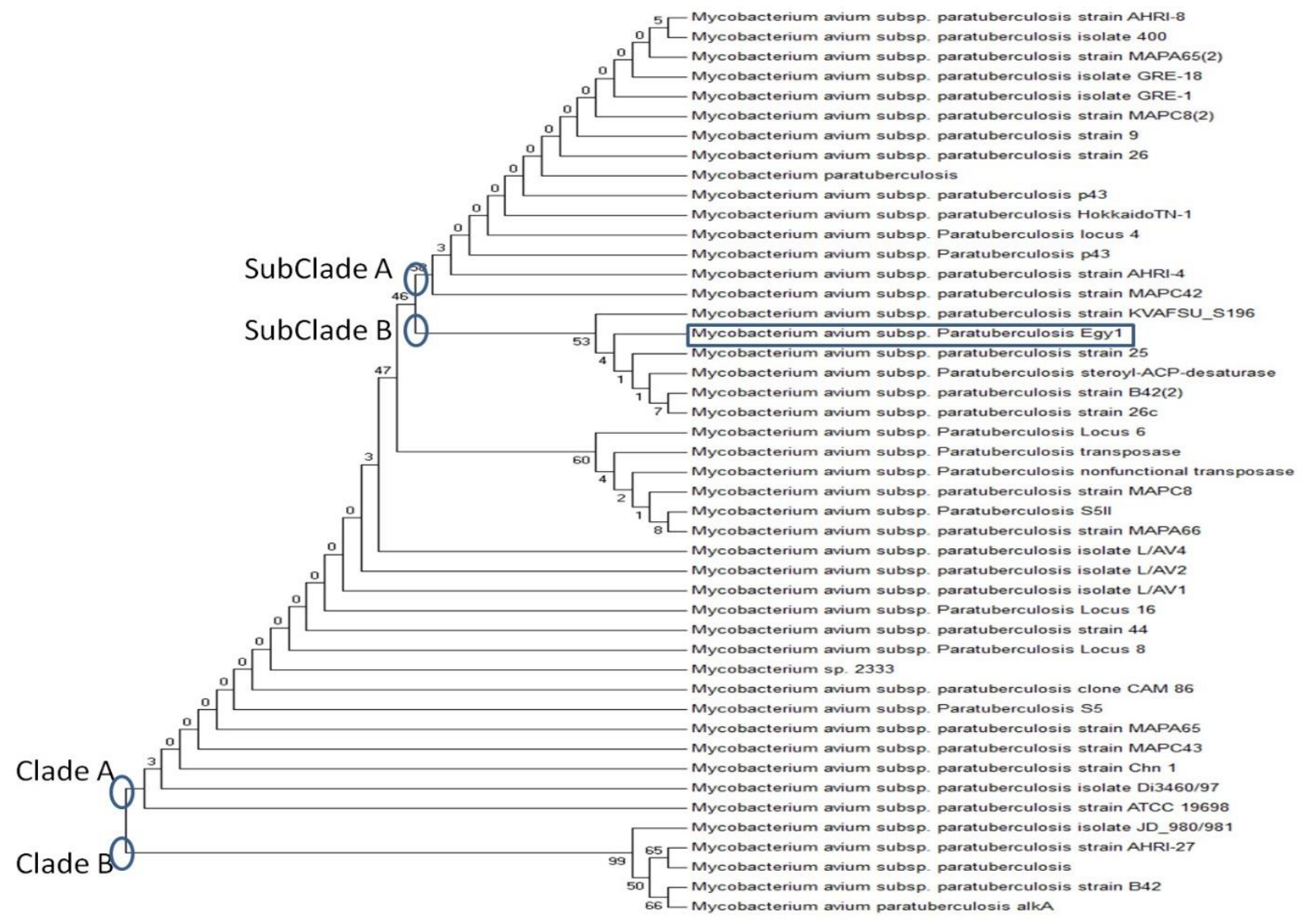

Figure 1: Phylogenetic analysis of different strains of MAP infection with our isolated strain"blue rectangle". phylogenetic tree was divided into two clades; clade A and clade B. Clade A was subdivided into two sub clades A and B where our isolated sequence (Mycobacterium avium subsp paratuberculosis EGY1) was located (sub-clade B)

\section{Discussion}

MAP has severe hazard to animal health. It causes significant economic losses to livestock animals worldwide. Limited studies were carried out to investigate MAP infection in Egypt, which directs our attention to this disease. Identification of MAP requires either culturing organisms in specific media or detecting the antibodies in sera of infected animals (33). The use of diagnostic markers to study the response of the host toward MAP infection is crucial for diagnosis of Johne's disease. Generally, ELISA is considered the most widely used test that assigned to detect MAP infection in animals. ELISA has been used in this study for the differentiation of the clinically affected cows from the sub-clinically infected cows. This based on the immune reaction of the microorganism in correlation to the presence or absence of the clinical signs in animals.

Alterations in the general health condition were observed. The heart rate, respiratory rate, and temperature remain normal which coincided with the previously reported data (4). The most common clinical signs reported in clinically affected cows were persistent diarrhea, chronic loss of body weight and dehydration which were nearly similar to those previously reported(34). The associated diarrhea may be due to the release of histamine as a result of antigen antibody reactions in the intestine (35). The characteristic thickened corrugated intestine by rectal examination might be attributed to the associated inflammatory process which involves the lymph node draining the intestine (36). The chronic loss of body weight might be 
due to the inflammation which resulted in thickening of the intestinal wall, leading to poor nutrient absorption in affected animals (4). Submandibular odema was observed in some cows, it might attribute to protein loss from the blood stream into the digestive tract (37).

Generally, the use of IS900 had been used extensively for studying MAP in domestic animals $(38,39)$. PCR positive result of MAP for IS900 can be used correctly in the identification of the causative agent for Johne's disease (40). Different sequences for IS900 were deposited in Genbank, besides the original sequence isolated from United Kingdom (X16293) (33) with a product size of around $1500 \mathrm{bp}$ which showed a change in a nucleotide sequence of our obtained sequence with a pair wise genetic difference of 0.009 .

Our obtained sequence of IS900 was identical to a sequence that was isolated from India (KY587112), while it was showing a higher difference when compared with other strains from Egypt (KJ173784 and KJ173784), although they were isolated from the fecal matter of cattle. In the two strains from Egypt, our isolated strain of MAP showed 98\% similarity index, but was named as transposase sequence where it is responsible for transposition of gene in prokaryotes. Insertion sequence regulates gene transposition (41). On the contrary, another isolated sample from Egypt (JN983503) was isolated from fecal matter of bovine species would find to share higher than $99 \%$ similarity index with our obtained sequence.

Johne's disease is reported to induce some hematological alterations. Significant decrease in the RBCs count and the PCV was reported in clinically affected cows when compared with sub-clinically infected and control ones. The significant decrease in the RBCs count is similar to that observed in JD clinically affected camels (42). Similar results of a significant decrease in PCV were also reported (43). These findings indicated the presence of anemia among the clinically affected cows, which is similarly reported before (44). Anemia is an important common extra intestinal complication associated with Crohn's disease in human. The microcytic hyperchromic anemia was reported in our study, where Crohn's disease show the same type of anemia which characterized by microcytic hyperchromic cells (45).

The use of serum biochemical parameters can be used as a diagnostic marker for certain diseases(46). Changes in the serum biochemical parameters were noticed. Significant decrease in the total protein in clinically affected cows was reported compared with sub-clinically infected and control cows. This was previously reported in the serum samples of positively infected cows with MAP (47). The hypoproteinemia might attributed to protein-losing enteropathy which might be due to the impaired integrity of the mucosa of the gastrointestinal tract (48) or due to the increase in the gut motility with a decreased in the absorption results in an increase in the intestinal loss of protein (43). Most of the cows suffer from clinical Johne's disease showed a low level of albumin with a normal level of globulin (49). Significant decrease in globulin was reported in our study. Hypoglobulinemia was previously reported in Crohn's disease which attributed to the decrease in globulin synthesis or increased catabolism of immunoglobulins (50). Hypoglycemia was reported in clinically affected cows when compared with sub-clinically infected and control cows. The presented findings matched with other researchers who reported hypoglycemia in response to gastrointestinal inflammatory disorders resulted from infection (51, 52). While serum biochemical parameters (cholesterol, triglycerides, ALT, AST, ALP, urea and creatinine) were reported to be non-significant changed. The non- significant change in the serum creatinine was similar to that observed in camel infected with JD (43).

With concern to oxidative and antioxidative markers, the non-significant changes in antioxidative markers (GST, GSH and TAC) in clinical and subclinical groups compared to the control group is nearly similar (53) who noted nonsignificant changes in serum superoxide dismutase and glutathione perioxidase activities of M. paratuberculosis positive cows. Non-significant changes in oxidative markers $\left(\mathrm{H}_{2} \mathrm{O}_{2}, \mathrm{NO}\right.$ 
and MDA) in clinically affected cows are indicative they are not associated with oxidative stress.

It could be concluded that the infection with the clinical form has a serious significant impact on the health of cows and the production of Egyptian dairy farms. A more continuous exact evaluation of its economic impact might provide a greater impact with an insight into the cost efficiency of detection and screening for subclinical infections, which could help in prevention the new infections and also improve the health and productivity of the herd. The parameters related with hemato-biochemical parameters such as glucose, total protein and globulin level in the present study may be considered in the differential diagnosis of clinical and subclinical $M$. paratuberculosis infection in dairy farms and waiting for further confirmation of the JD by definitive tests as culture, ELISA and PCR. Still more deep investigation on a large scale is needed to identify the number of cases affected with JD in different localities in Egypt.

\section{References}

1. Norton S, Johnson WO, Jones G, Heuer C. Evaluation of Diagnostic Tests for Johne's Disease (Mycobacterium Avium Subspecies Paratuberculosis) in New Zealand Dairy Cows. Journal of Veterinary Diagnostic Investigation 2010; 22 (3):341-51.

2. Pieper L, Sorge US, DeVries TJ, Godkin A, Lissemore K, Kelton DF. Evaluation of the Johne's disease risk assessment and management plan on dairy farms in Ontario, Canada. Journal of dairy science 2015 ; 98 (10):6792-800.

3. Lombard JE. Epidemiology and economics of paratuberculosis. Veterinary Clinics: Food Animal Practice 2011; 27 (3):525-35.

4. Salem M, Heydel C, El-Sayed A, Ahmed SA, Zschöck M, Baljer G. Mycobacterium avium subspecies paratuberculosis: an insidious problem for the ruminant industry. Tropical Animal Health and Production 2013; 45 (2):351-66.

5. Tewari D, Hovingh E, Linscott R, Martel E, Lawrence J, Wolfgang D, Griswold D. Mycobacterium avium subsp. paratuberculosis (MAP) Antibody Response, Fecal shedding and Antibody Cross-reactivity to Mycobacterium bovis in MAP Infected Cattle Herds Receiving Johne's Vaccination. Clinical and Vaccine Immunology 2014; 00032-00014.
6. Beaudeau F, Belliard M, Joly A, Seegers H. Reduction in milk yield associated with Mycobacterium avium subspecies paratuberculosis (Map) infection in dairy cows. Veterinary Research 2007; 38 (4):625-34.

7. Chiodini RJ, Chamberlin WM, Sarosiek J, McCallum RW. Crohn's disease and the mycobacterioses: a quarter century later. Causation or simple association? Critical Reviews in Microbiology 2012; 38 (1):52-93.

8. Gilardoni LR, Paolicchi FA, Mundo SL. Bovine paratuberculosis: a review of the advantages and disadvantages of different diagnostic tests. Rev Argent Microbiol 2012; 44 (3):201-15.

9. Bölske G, Herthnek D. Diagnosis of Paratuberculosis by PCR. Paratuberculosis: Organism, Disease, Control 2010; 267.

10. Sohal J, Singh S, Subodh S, Shoran N, Narayanasamy K, Singh P, Singh A, Maitra A. Mycobacterium avium subspecies paratuberculosis diagnosis and geno-typing: Genomic insights. Microbiological Research 2009; 164 (3):330-37.

11. Rosenberger G. Die Klinische Untersuchung des Rindes. 3rd ed. Paul Parey, Berlin,München. InTech 1990.

12. Manual OT. Paratuberculosis (Johne ${ }^{\text {ee }} \mathrm{s}$ disease) Section 2.1. Chapter 2008.

13. Kalis C, Hesselink J, Barkema H, Collins M. Culture of strategically pooled bovine fecal samples as a method to screen herds for paratuberculosis. Journal of Veterinary Diagnostic Investigation 2000; 12: 547-51.

14. Fernández-Silva J, Abdulmawjood A, Bülte M. Diagnosis and molecular characterization of Mycobacterium avium subsp. paratuberculosis from dairy cows in Colombia. Veterinary Medicine International 2011; 352561.

15. Vary P, Andersen P, Green E, HermonTaylor J, McFadden J. Use of highly specific DNA probes and the polymerase chain reaction to detect Mycobacterium paratuberculosis in Johne's disease. Journal of Clinical Microbiology 1990; 28 (5):93337.

16. Tamura K, Stecher G, Peterson D, Filipski A, Kumar S. MEGA6: molecular evolutionary genetics analysis version 6.0. Molecular Biology and Evolution 2013; 30: 2725-9.

17. Dacie JV. Dacie and Lewis practical haematology. Elsevier Health Sciences 2006.

18. Trinder P. Determination of glcose in blood using glucose oxidase with an alternative oxygen acceptor. Annals of Clinical Biochemistry 1969; 6 (1):24-27. 
19. Allain CC, Poon LS, Chan CS, Richmond W, $\mathrm{Fu}$ PC. Enzymatic determination of total serum cholesterol. Clinical Chemistry 1974; 20 (4):470 75.

20. Fossati P, Prencipe L. Serum triglycerides determined colorimetrically with an enzyme that produces hydrogen peroxide. Clinical Chemistry 1982; 28(10):2077-80.

21. Lowry $\mathrm{OH}$, Rosebrough $\mathrm{NJ}$, Farr $\mathrm{AL}$, Randall RJ. Protein measurement with the Folin phenol reagent. Journal of Biological Chemistry 1951; 193 (1):265-75.

22. Doumas B, Biggs H. Determination of Serum albumin: In standard methods of Clinical Chemistry (Cooper GA) Academic press Inc. New York 1972; 1:175

23. Reitman S, Frankel S. A colorimetric method for the determination of serum glutamic oxalacetic and glutamic pyruvic transaminases. American Journal of Clinical Pathology 1957; 28 (1):56-63.

24. Hausamen T-U, Helger R, Rick W, Gross W. Optimal conditions for the determination of serum alkaline phosphatase by a new kinetic method. Clinica Chimica Acta 1967; 5 (2):241-45.

25. Heinegård D, Tiderström G. Determination of serum creatinine by a direct colorimetric method. Clinica Chimica Acta 1973; 43 (3):305-10.

26. Marsh WH, Fingerhut $B$, Miller $H$. Automated and manual direct methods for the determination of blood urea. Clinical Chemistry $1965 ; 11(6): 624-27$.

27. Koracevic D, Koracevic G, Djordjevic V, Andrejevic S, Cosic V. Method for the measurement of antioxidant activity in human fluids. Journal of Clinical Pathology 2001; 54 (5):356-61.

28. Habig WH, Pabst MJ, Jakoby WB. Glutathione S-transferases the first enzymatic step in mercapturic acid formation. Journal of Biological Chemistry 1974; 249 (22):7130-9.

29. Beutler E. Improved method for the determination of blood glutathione. J Lab Clin Med 1963; 61:882-88.

30. Frew JE, Jones P, Scholes G. Spectrophotometric determination of hydrogen peroxide and organic hydropheroxides at low concentrations in aqueous solution. Analytica Chimica Acta 1983; 155:139-50.

31. El-Bayomi K M, Saleh A A, Awad A, ElTarabany M S, El-Qaliouby H S, Afifi M, El-Komy S, Essawi W M, Almadaly E A, El-Magd M A. Association of CYP19A1 gene polymorphisms with anoestrus in water buffaloes, Reproduction, Fertility and Development 2018; 30(3): 487-97.
32. Nims RW, Darbyshire JF, Saavedra JE, Christodoulou D, Hanbauer I, Cox GW, Grisham MB, Laval F, Cook JA, Krishna MC. Colorimetric methods for the determination of nitric oxide concentration in neutral aqueous solutions. Methods 1995; 7 (1):48-54.

33. Green E, Tizard M, Moss M, Thompson J, Winterbourne D, McFadden J, Hermon-Taylor J. Sequence and characteristics or IS 900, an insertion element identified in a human Crohn's disease isolate or Mycobacterium paratuberculosis. Nucleic Acids Research 1989; 17 (22):9063-73.

34. Harris NB, Barletta RG. Mycobacterium avium subsp. paratuberculosisin veterinary medicine. Clinical Microbiology Reviews 2001; 14 (3):489-512.

35. Tiwari A, VanLeeuwen JA, McKenna SL, Keefe GP, Barkema HW. Johne's disease in Canada: Part I: Clinical symptoms, pathophysiology, diagnosis, and prevalence in dairy herds. The Canadian Veterinary Journal 2006; 47 (9): 874-82.

36. Clarke C. The pathology and pathogenesis of paratuberculosis in ruminants and other species. Journal of Comparative Pathology 1997; 116 (3):217-61.

37. Manning E, Collins M. Mycobacterium avium subsp. paratuberculosis: pathogen, pathogenesis and diagnosis [Johne's disease, paratuberculosis]. Revue Scientifique et Technique de l'OIE (France) 2001; 20(1):133-50.

38. Hulten K, Karttunen T, El-Zimaity H, Naser S, Collins M, Graham D, El-Zaatari F. Identification of cell wall deficient forms of $M$. avium subsp. paratuberculosis in paraffin embedded tissues from animals with Johne's disease by in situ hybridization. Journal of Microbiological Methods 2000; 42: 185-95.

39. Bauerfeind $\mathrm{R}$, Benazzi $\mathrm{S}$, Weiss $\mathrm{R}$, Schliesser T, Willems H, Baljer G. Molecular characterization of Mycobacterium paratuberculosis isolates from sheep, goats, and cattle by hybridization with a DNA probe to insertion element IS900. Journal of Clinical Microbiology 1996; 34: 1617-21.

40. Motiwala AS, Strother M, Amonsin A, Byrum B, Naser SA, Stabel JR, Shulaw WP, Bannantine JP, Kapur V, Sreevatsan S. Molecular epidemiology of Mycobacterium avium subsp. paratuberculosis: evidence for limited strain diversity, strain sharing, and identification of unique targets for diagnosis. Journal of Clinical Microbiology 2003; 41: 2015-26. 
41. Mahillon J, Chandler M. Insertion sequences. Microbiology and Molecular Biology Reviews 1998; 62: 725-74.

42. El-Deeb W, Fouda T, El-Bahr S. Clinicobiochemical investigation of paratuberculosis of Dromedary camels in Saudi Arabia: Proinflammatory cytokines, acute phase proteins and oxidative Stress Biomarkers. Pakistan Veterinary Journal 2014; 34 (4): 484-88.

43. Tharwat M, Al-Sobayil F, Ali A, Hashad M, Buczinski S. Clinical, ultrasonographic, and pathologic findings in 70 camels (Camelus dromedarius) with Johne's disease. The Canadian Veterinary Journal 2012; 53 (5):543-48.

44. Weiss G, Goodnough LT. Anemia of chronic disease. New England Journal of Medicine 2005; 352 (10):1011-23.

45. Park BS, Park S, Jin K, Kim YM, Park KM, Lee J-N, Kamesaki T, Kim YW. Coombs-Negative Autoimmune Hemolytic Anemia in Crohn's Disease. The American Journal of Case Reports 2014; 15:550-53.

46. Moore RE, Kirwan J, Doherty MK, Whitfield PD. Biomarker discovery in animal health and disease: the application of post-genomic technologies. Biomarker insights 2007; 2: 185-96.

47. Donat K, Erhardt G, Soschinka A, Brandt H. Decreased serum protein associated with Mycobacterium avium subspecies paratuberculosis shedding in German Holstein cows. Vet Rec 2014;
174 (16): 408.

48. Sweeney R, Collins M, Koets A, McGuirk S, Roussel A. Paratuberculosis (Johne's disease) in cattle and other susceptible species. Journal of Veterinary Internal Medicine 2012; 26 (6):123950.

49. Brady C, O'Grady D, O'Meara F, Egan J, Bassett H. Relationships between clinical signs, pathological changes and tissue distribution of Mycobacterium avium subspecies paratuberculosis in 21 cows from herds affected by Johne's disease. Veterinary Record 2008; 162 (5):147-52.

50. Elson CO, James SP, Graeff AS, Berendson RA, Strober W. Hypogammaglobulinemia due to abnormal suppressor T-cell activity in Crohn's disease. Gastroenterology 1984 ; 86 (3):569-6.

51. .Kamal AM. Some biochemical, heatological and clinical studies of selected ruminal and blood constituents in camels affected by various diseases. Res J Vet Sci 2008; 1 (1):16-27.

52. Salem M, El-Sayed A, Fayed A, Abo ElHassan D. Subclinical infection of paratuberculosis among camels in Egypt. Journal of American Science 2012; 8:1141-47.

53. Cenesiz M, Ciftci G, Dalgin D, Kilic Y, Gul FY, Cenesiz S. Evaluation of Oxidant and Antioxidant Capacity in Paratuberculosis Positive Cattle. Pakistan Journal of Zoology 2016; 48 (5): :1603-06. 